\title{
Marketing Personnel Training Reform on "Theory + Case + Simulation + Practice" Four-in-One Teaching Mode
}

\author{
Shijie Zhang \\ College of Finance and Trade, Bohai University, Jinzhou, 121013, China \\ 2824834538@qq.com
}

\begin{abstract}
Keywords: marketing; personnel training mode; four-in-one teaching mode; theory teaching; case teaching; simulation teaching; practice teaching
\end{abstract}

\begin{abstract}
With the intensifying of market competition, the enterprise demand for marketing personnel is more and more strong, be badly in need of knowledge of enterprise management and marketing technology applied talents. Traditional personnel training mode there are a lot of disadvantages, this paper put forward "theory + case + simulation+ practice" four one of the talent training mode reform. Four kinds of teaching way connect with each other and promote each other, mutually conditional and integral. Among them, the theory of teaching, cultivate students solid theoretical knowledge; Case teaching, trains the student to put forward solutions of case; Simulation teaching, with the aid of simulation environment, the role and activities, to help students understand the theoretical knowledge and master skills; The practice teaching, the thorough enterprise actual operation and exercise, experience marketing risk and complexity.
\end{abstract}

\section{Introduction}

Marketing is in the creation, communication, communication and exchange in the process of the products, for customers, clients, partners and the society as a whole value activity, process and system. Is mainly refers to the marketing personnel in response to carry out business activities and market sales process. The first purpose is to create a customer marketing, obtain and maintain customer; From a long-term point of views to consider how to effectively overcome competitors, in an impregnable position. Only pay attention to market research, collect and analyze large amounts of information, can in the environment and the market changes to make the right decision; To make decisions in the change, decision makers are required to have a strong ability, be like entrepreneurs insight, discrimination, and determination.

With the intensifying of market competition, the demand for marketing professionals is all walks of life. Especially in recent years, the market marketing professional ranks high in the list of the national talent market demand. According to the proportion of the industrial structure analysis, China has conducted a greater adjustment of industrial structure, industrial structure is reasonable, and the employment structure has changed greatly. According to the labour market statistics and forecast, the next few years in marketing and international trade specialized talented person demand, etc.; According to the proportion of industry demand analysis, the labour market to engage in commodity wholesale, retail, catering, as well as the demand for services has been rising, and the number of demand far more than any other industry, most of these are in the marketing work; Chinese enterprise marketing job's weakest link is the lack of professional team, led directly to the enterprise's own marketing system and customer system out of control, financial risk and the enterprise economic benefit is poor marketing is the first element of success, only by establishing has a keen market observation and strong ability of marketing analysis to determine the marketing team, to ensure normal operation of the enterprise marketing system and customer system, reduce financial risk, and improve the economic benefit. Training to adapt to the development of Chinese market economy need, therefore, the marketing manager is the urgent task facing education workers.

Marketing major is training to adapt to the socialist market economy need to develop morally, intellectually and physically, understand the market economy, solid foundation, broad scope, know 
both marketing and management practice, and familiar with the state economic and trade policies and laws, able to skillfully use the computer, know the import and export business, familiar with foreign trade knowledge, the knowledge of enterprise management and marketing technology, strong practice ability of applied talents. The traditional training mode has not adapted to the new situation, the demand for marketing personnel. This paper puts forward "theory + case ++ simulation practice" four one training mode, namely the theory teaching, case teaching, simulation teaching and practice teaching and so on four kind of training mode of comprehensive. Among them, the theoretical teaching, students are required to possess solid theoretical knowledge, and be able to use theoretical knowledge to analysis to solve the practical problems in marketing activities; Case teaching, case can ask students to put forward the solution to solve the problem independently, outstanding student's main body status; Simulation teaching, with the aid of simulation environment, the role and activities, to help students understand the theoretical knowledge, mastering skills; The practice teaching, moves towards the society, the thorough enterprise actual operation and exercise, experience marketing risk and complexity. Theory teaching provides the basis for the other three, and practice teaching is the practical application of the other three teaching. Four kinds of teaching way to contact each other, promote each other, each other conditions, be short of one cannot, embodies the "student-centered" and "demand oriented" thought of constructivism, to ensure that students from the multi-level and multi-angle, all-round marketing knowledge training. Promote students to actively take part in the marketing practice, realize the significance of the subject construction, finally forms the analysis and solution actual problem ability has a great effect.

\section{Theory Teaching Method}

Theory is the foundation of the teaching process of teaching, is the starting point of all knowledge transfer and the cornerstone. The role of theoretical teaching not only embodies in structures, knowledge structure, the more important is to guide practice, on the basis of predecessors' experience to create new achievements, to provide guidance in the field of knowledge innovation. Practice teaching is not an isolated existence, cannot be separated from the guidance of the theory teaching, no theoretical support and practical teaching can't be. "Denial theory, is refused to progress, are the low levels of simple repeated". As a result, we must attach importance to theoretical knowledge learning.

Theory teaching characteristics: strong logicality, every course has related concepts and definitions, judgment and reasoning should follow the corresponding principle, axioms and theorems, therefore the high requirement of abstract thinking; Purpose is clear, all of the concepts, judgment and reasoning are in order to obtain the correct answer to the final, easy to form a single direction and mind-set, dispersing thinking. The present classroom teaching problems are as follows: self-study is not high, learning attitude is not very good, the study purpose is not strong, concentration; The lack of a certain way to learn, in a passive state, difficult to grasp the key and difficult; Continuity and systematic of the course itself is stronger, causing students in front of the learning task more learning ability is low, the serious influence the teaching effect; Student to the interest theory course, truancy, late or do other unrelated to work in the classroom. Therefore, a set of practical and effective methods must be taken to mobilize students' enthusiasm, must be involved in the course to students.

Marketing theory included management principle, western economics, statistics, consumer psychology, marketing and logistics management, and etc. Among them, the principles of management, focuses on the basic concepts and principles of management, the evolution of western management thoughts and the enlightenment, management of the basic functions of management of internal and external environmental analysis and etc.; Western economics, make the students master the basic knowledge and analysis method, the basic content of contemporary economics has a comprehensive and systematic understanding, analysis and application, and can be combined with the actual foundation for other courses of study and work; Statistics theory, explore the number of objective things inherent regularity, grasp the concepts, principles and methods of the statistical work of the main link, and can use these principles and methods to solve practical problems; 
Consumer psychology, grasps the consumer psychology and the change law of development, improve the ability of judgment and analysis of the consumers, improve the decision-making ability of organization in the marketing activities; Marketing, require students to firmly establish a modern market concept, correctly for the determination of market segmentation and target market, grasp the product pricing, sales channels, and promotion strategy, skilled use of modern marketing strategies and methods; Logistics management, master of logistics management best practices and the important link, understand the new trend of logistics management and improving direction, solve the practical problems in the current logistics management.

\section{Case Teaching Method}

Case teaching is a kind of simulation or recreate real-life scenarios, let the students themselves into the case scenario, through discussion or seminars to study a kind of teaching method, mainly used in the management disciplines and law, is now also widely used in clinical medical teaching. Either through analysis and comparison in the teaching, study all kinds of success and failure of management experience, which abstracts the conclusion or management of some general principle, also can let students think through their own or other people's thinking to broaden their horizons, to enrich their own knowledge. Case teaching to try to avoid to have no practical experience of the students as the object, but also to pay attention to the content of the selected cases and the correlation of students' practical experience, to try to students with diverse background together, as a case discussion of different experience, information, knowledge and ideas lay a foundation of communication and interaction.

Case teaching around the teaching aim of marketing, and let the students themselves into the marketing case scenario, in the form of discussion or seminars to study marketing. Teachers should be in the whole process of the case teaching method into the teaching of marketing, to create a scientific and rigorous, pay attention to theory, lively, pay attention to practical teaching effect. Specific role is: is good for students to master and understand what they have learned knowledge of marketing theory, to students with immersive feeling, to strengthen the students' perception of marketing theory, in the mutual exchange to deepen the understanding of marketing theory knowledge; To cultivate students' ability to analyze and solve practical problems of marketing, as one of the students officially enter the marketing practice before the preview, shorten the distance between the marketing theory and practice; Is beneficial to create a blend of marketing of lively teaching atmosphere between teachers and students, stimulate students' active thinking, put forward the solution to solve the problem and ways, at the same time teachers duly guided and complementary; Effectively improve the level of teachers' professional quality and basic teaching research, teachers need to teach marketing, on the basis of the organic combination of knowledge and case study, summarize and improve constantly.

Case selection directly affect the quality of marketing teaching, in the teaching activities of the marketing, teachers need to choose science teaching cases, combined with marketing professional students' practical ability and requirements in terms of teaching design. In the process of case selection, should follow the characteristics of typicality and operability. In terms of representativeness, need to select the typical marketing case, for example, make a comprehensive analysis of the specific issues that exist in the present case the theory of value, closely associated with the actual situation of the current marketing. In terms of operability, so that the students can fully involve among them, stimulate interest in learning, focus on the marketing teaching work for students in the future, so that the students can use the knowledge by learning to solve the problem of all kinds of marketing.

\section{Simulation Teaching Method}

Simulation teaching method is to point to in under the guidance of teacher, students and play a certain role or creating a tutor in the background, the real miniature to simulate the situation in the classroom, and using the special teaching tool to simulate the speech of a non-traditional mode of 
teaching method. The significance of simulation teaching is to create a highly simulation teaching environment, the combination of theory and practice of construction of the bridge, the enhancement of the interactive teaching and cognitive, interpret the behavior characteristics of students, make students improve and comprehension. Simulation teaching method has many characteristics, such as interactive, interesting and competitive, can maximum limit arouses student's study interest, make students in a highly excited state, make full use of listening, speaking, learning, doing and change, and a series of learning methods, open all the senses can mobilize memory formation depth of learning content, and will learn about the management ideas and methods in actual work practice and use. In the simulation teaching of middle school students get is no longer a hollow concepts and theories, but precious practical experience and deep understanding and comprehension.

Combined with marketing major courses blend mutually and penetration of inner link, according to the characteristics of the society for marketing professionals needs, on the basis of existing theory teaching and practice teaching, build a marketing major simulation experiment teaching system, should follow the following principles: pay attention to personnel training and combination of economic and social needs, pay attention to personnel training combined with the advantage of school discipline, pay attention to the integration with theory, practice and experiment teaching, pay attention to the development of marketing management ability oriented goals.

Due to the marketing of professional class category is more, utility is huge, simulation teaching organization shall be carried out in a gradual manner, namely shallow simulation first, deepen with the professional knowledge, constantly increase the depth and difficulty, according to the behavior simulation, analysis, simulation, process simulation and the order of the management and integrated simulation and steps, to develop the students' ability of practical marketing better. Simulation teaching to find accurate career orientation, reflect the occupational of marketing major, provides the real or simulation of professional environment, feel the enterprise culture, pay attention to professional quality discipline, strengthen students' market concept, product concept and quality consciousness. To develop students to investigate, the team exercise ability and eloquence. Class character simulation teaching, only through practice can really master the teaching content is given priority to with simulated teaching method, including simulation and simulation method such as business negotiations. Should make full use of various resources design simulation face-to-face teaching content, and improve the effect of simulated teaching.

\section{Practice Teaching Method}

Practice teaching is to consolidate theoretical knowledge and an effective way to deepen understanding of the theory, is to cultivate innovative high-quality engineering and technical personnel of important link, is the theory with practice, cultivate the students master the scientific method, and the ability to practice and important platform. It can improve students' quality and the formation of the correct values. Practice teaching contents including experiment, practice, practice, social practice, course design, graduation design and graduation thesis and academic papers and so on, also including military training, entrepreneurship, and the social investigation into the teaching plan, technology production, subject contests, etc. These contents to form a scientific and reasonable system, and plays an important role in talent training goals.

Marketing major practice teaching mode, should from the companies need according to the marketing personnel quality and ability of using system's point of view, for marketers need ability of decomposition and integration, and ability to the process and mechanism of formation, as the basis of practice teaching design, satisfies the requirement of enterprise marketing ability of specialized personnel. In the practice teaching, emphasizing the application of knowledge, makes students theory applied in the practical teaching, improve quality and enhance ability, solve the current marketing major in teaching practice and theory disjointed problem; The idea of modular and incremental design, practice teaching can be divided into basic skills training, marketing simulation teaching and practical teaching three modules, and reasonable distribution in the teaching plan, ability embodies law of development and the formation mechanism of requirements; Starting from the teaching module and link two dimensions, USES the matrix structure design 
practical teaching plan, highlight the diversity of practice teaching plan, coordination and systemic; In the practice teaching design, emphasis on teaching method innovation, open mode of practice teaching, heuristic, interactivity, experience and information, etc.

Specific marketing professional practice teaching system can include four aspects: one is that the classroom experiments, selection and training post ability directly related, and using the professional knowledge content, higher frequency the abilities of jobs need a reasonable distribution of module and knowledge base to the main course. Promotes cooperation with enterprises, will be moved to the workplace, is helpful for students to marketing professional related industries have a more clear understanding, mastering the basic skills is more close to the actual market; Second, practice teaching, the individual skills for marketing positions need intensive training, distribution in marketing professional backbone course, the arrangement of a week of practice teaching, to complete the corresponding individual skills. In teaching practice, based on a real project to carry out market research, enterprise diagnosis and marketing planning project, market research planning practice training; Three is, professional training, it is independent of the teaching of practice teaching course alone, is the focus of the practical teaching system, practice teaching difficulty, need to various support and cooperation to achieve the desired effect. Can organize marketing students participate in marketing planning scheme design competition to select, build the atmosphere of competition of marketing ability, ability to cultivate students the comprehensive application of marketing knowledge; Four, field work, mainly on enterprise expert guidance, school teachers guidance is complementary. In last semester before graduation, jobs choose to school recommendation and choosing the way of combining students'. Students into the real marketing operation of the enterprise, make the school have learned to be tested in practice.

\section{References}

[1] Y. F. Yan, Y. L. He, "On the combination of practical teaching and theoretical teaching," Electronic Test, vol. 23, no. 8, pp. 174-175, 2016.

[2] Y. Q. Zhai, "Analysis on the demand of marketing professional talents in China," Co-Operative Economy \& Science, vol. 20, no. 17, pp. 13-14, 2006.

[3] J. Li, "Marketing in Higher Vocational Education: a new system of practical teaching," Vocational Education Research, vol. 30, no. 12, pp. 130-132, 2011.

[4] M. Shen, "The application of case teaching method in Marketing Teaching," Modern Economic Information, vol. 31, no. 12, pp. 368-368, 2016.

[5] J. D. Hou, "Teaching System Construction of Simulation - Based Experiment for Marketing in the Higher Education," Journal of Hubei University of Education, vol. 33, no. 1, pp. 91-94, 2016.

[6] Q. Chen, "On the construction of simulation teaching system of marketing specialty in Higher Vocational Colleges," Journal of Hubei Adult Education Institute, vol. 16, no. 4, pp. 128-129, 2010. 